\title{
Cinema e engajamento político:
}

\section{Entrevista com Helena Solberg}

\section{Por Ceiça Ferreira}

Helena Solberg estreia como diretora em 1966 com o curta-metragem A entrevista, documentário no qual problematiza a condição feminina e as assimetrias de gênero no contexto da classe média carioca. Dessa forma, a diretora utiliza o cinema como um lugar de encontro, partilhando com outras mulheres suas próprias inquietações acerca de temas como casamento, sexo, filhos, estudos e carreira. Tais questões que poderiam ser consideradas apenas no âmbito pessoal são articuladas no filme com uma reflexão mais ampla da sociedade brasileira, em especial pelo contexto social e político, com a Marcha da Família com Deus pela liberdade e o golpe militar de 1964. Além do modo reflexivo de representação, também o uso da ficção no documentário com a preparação de uma noiva, encenação da qual emergem as falas das entrevistadas, faz com que "o documentário de Helena Solberg já nasça moderno", conforme aponta Tavares (2014, p. 17).

Em seu segundo filme e primeira ficção, o curta Meio-dia (1970), Helena Solberg utiliza o ambiente escolar como alegoria da ordem social vigente, mas também destaca a rebeldia infantil. Crianças e adolescentes matam o professor, destroem a escola e comemoram brincando e dançando num momento festivo, que tem como trilha sonora a canção "É proibido proibir", de Caetano Veloso (ARAÚJO; SOUTO, 2018). Dessa forma, suas primeiras produções indicam o engajamento político que será uma constante em sua filmografia.

A partir de 1971, Helena passa a morar nos Estados Unidos e, com o desejo de fazer um filme sobre a história do movimento feminista no país, conhece militantes no meio universitário de Washignton-DC, juntamente com as quais realiza, em 1974, em uma experiência de criação coletiva, o média metragem The emerging woman (A Nova Mulher). Nesse projeto são utilizadas vozes femininas na interpretação de textos escritos por ativistas, além de imagens de arquivo, fragmentos de discursos, filmes e propagandas antigas para contar 200 anos de história da luta das mulheres. 


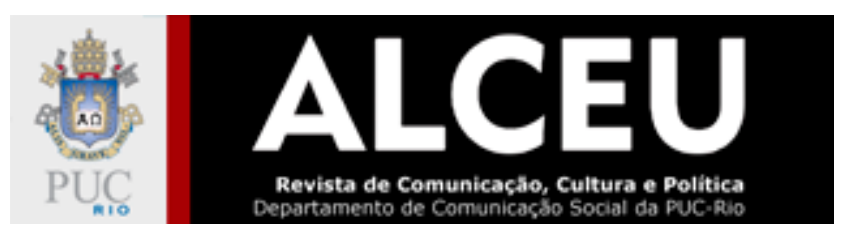

Reconhecido como um importante documento histórico, The emerging woman marca o surgimento do grupo International Women's Project, organização independente composta por Helena e outras participantes de várias nacionalidades; e, principalmente, possibilita a realização dos próximos filmes que irão abordar, sob uma perspectiva feminista, a realidade de mulheres latino-americanas. As desigualdades de gênero no contexto familiar e no mercado de trabalho são discutidas em The Double Day (A Dupla Jornada, 1975), que desnaturaliza os lugares sociais impostos a homens e mulheres e reflete sobre a exploração da força de trabalho feminina nas atividades domésticas e nas fábricas. Já em Simplesmente Jenny (1977), a diretora propõe uma leitura crítica dos modelos de feminilidade e pureza transmitidos pela mídia e pela formação cristã, confrontando-os com as histórias de três meninas bolivianas (Patricia, Marly e Jenny) que estão em um reformatório e compartilham experiências de violência sexual e prostituição.

Nos anos seguintes, Helena Solberg realiza os documentários Das cinzas...Nicarágua Hoje (1982), A Conexão Brasileira, a luta pela democracia (1982/1983), Chile, pela razão ou pela força (1983), que investigam as relações políticas entre os Estados Unidos e a América Latina e a mobilização popular frente aos regimes totalitários; e, no contexto brasileiro, a expectativa de eleições após 18 anos de ditadura militar, aliada à crise econômica com o aumento da dívida externa. Posteriormente, a cineasta também dirige Retrato de um Terrorista (1985), que tem como foco os sequestros de motivação política; e ainda Terra dos Bravos (1986) e A Terra Proibida (1990), documentários que mostram a luta pela terra, empreendida por lideranças indígenas em diferentes países; e também no Brasil, com a atuação da ala progressista da Igreja Católica e seu apoio à luta dos trabalhadores sem-terra. A partir de um posicionamento que descortina as relações de poder, esses filmes indicam a perspectiva dos oprimidos como possibilidade de construção histórica (AMARAL; ITALIANO, 2018).

No documentário Carmen Miranda: Bananas Is My Business (Carmen Miranda, Meu Negócio é Bananas,1994), Helena Solberg retorna à temática feminina ao construir o que ela chama de biografia afetiva de Carmen, cantora luso-brasileira que se torna a representação do nosso país e da América Latina no contexto da política da Boa Vizinhança entre Brasil e EUA, no período da Segunda Guerra Mundial. Essa abordagem afetiva se expressa na forma como a diretora, a partir de um relato pessoal e íntimo, expõe os desafios encontrados na pesquisa e coleta de documentos ao longo de três anos, assim como os próprios dramas vividos pela cantora, como por exemplo diante das críticas de te ser americanizado e do desafio de traduzir a música e cultura brasileira 
para a América do Norte. Aliada a essa pesquisa minuciosa, a memória de pessoas que conviveram e trabalharam com a artista, bem como o uso da ficção para mostrar Carmem Miranda adolescente (interpretação da atriz Letícia Monte) e adulta (atuação do ator e transformista Erik Barreto) são elementos que confirmam a relevância desse documentário na história do cinema nacional, em especial no período da retomada. Prova disso foram os prêmios recebidos em vários festivais, como o Festival de Brasília e de Havana, e as diversas exibições em mostras nacionais e internacionais (TAVARES, 2014; 2017b).

Em 1996, o sucesso editorial do lançamento da revista RAÇA (publicação direcionada ao público negro) contrariou todas as expectativas e foi tema do documentário Brasil em Cores Vivas (1997), que Helena Solberg fez para a Channel 4 Television da Inglaterra. O filme apresenta entrevistas com o criador da revista, o jornalista Aroldo Macedo, além de atrizes, cineastas e militantes do Movimento Negro, como Zezé Motta, Taís Araújo, Luiz Antonio Pilar e Sueli Carneiro numa reflexão sobre a necessidade de criar novas narrativas e novos regimes de visibilidade para a população negra brasileira.

O reconhecimento alcançado com Carmen Miranda: Bananas Is My Business possibilita a Helena Solberg realizar a produção do longa-metragem de ficção Vida de Menina (2004), uma adaptação do livro Helena Morley, Minha Vida de Menina, da escritora Alice Dayrell Caldeira Brant (1942). Esse filme, realizado um ano depois do retorno da diretora ao Brasil, integra a fase atual de sua carreira, na qual também se inserem os documentários Palavra (En)cantada (2009), que investiga as relações entre poesia e música popular, e Alma da Gente (2013), no qual ela relaciona as expectativas de dez anos antes com a realidade atual de adolescentes que participaram do projeto Corpo de Dança da Maré, coordenado pelo coreógrafo Ivaldo Bertazzo.

Meu Corpo Minha Vida (2017) é o trabalho mais recente de Helena Solberg e destaca um assunto urgente: o aborto. A partir da morte de Jandyra dos Santos em decorrência de um aborto realizado em uma clínica clandestina, a diretora retoma a perspectiva feminista e as questões já trabalhadas em seus primeiros filmes, como o modelo idealizado de mulher e de casamento, agora inseridos em um contexto marcado pela posição retrógrada de grupos e políticos evangélicos; e também a mobilização de mulheres, que vão às ruas protestar contra a violência e a opressão e em defesa da descriminalização do aborto e da liberdade de seus corpos (TAVARES, 2017a; 2017b). 


\section{ALCEU

Esse breve panorama da obra e da trajetória singular de Helena Solberg nos possibilita repensar a história do cinema brasileiro. Mesmo com 50 anos de carreira e uma filmografia que abrange o Cinema Novo, a militância feminista nos Estados Unidos e na América Latina, a ficção e o documentário contemporâneo, essa cineasta ainda é pouco conhecida no Brasil.

Somente em 2014, no É Tudo Verdade - Festival Internacional de Documentários, essa lacuna começa a ser reparada com uma mostra de seus principais filmes e o lançamento do livro Helena Solberg: do cinema novo ao documentário contemporâneo, da pesquisadora Mariana Tavares; também em março de 2018, o Centro Cultural Banco do Brasil realizou uma mostra integral de sua obra em Brasília, São Paulo e no Rio de Janeiro; nesse mesmo ano a quarta edição do Pirenópolis Doc - Festival de Documentário Brasileiro apresentou uma mostra retrospectiva com oito filmes de Helena Solberg. A entrevista que se segue foi realizada como parte do trabalho de curadoria dessa mostra, que reitera a vitalidade e o legado crítico da filmografia dessa cineasta.

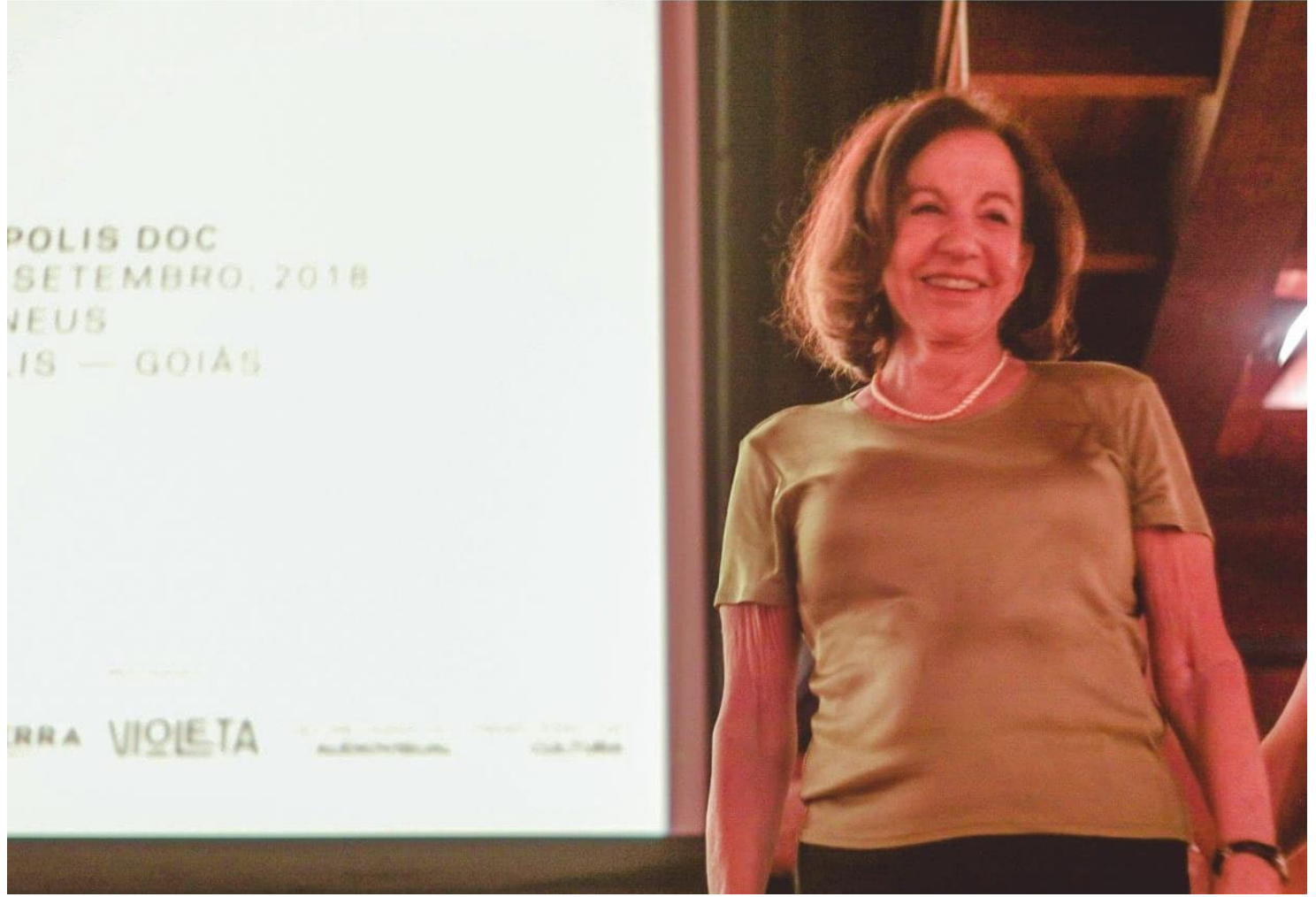

Figura 1: Helena Solberg no IV Pirenópolis Doc - Festival de Documentário Brasileiro, 2018. Fonte: Divulgação do Festival. Foto: Pedro Henrique 


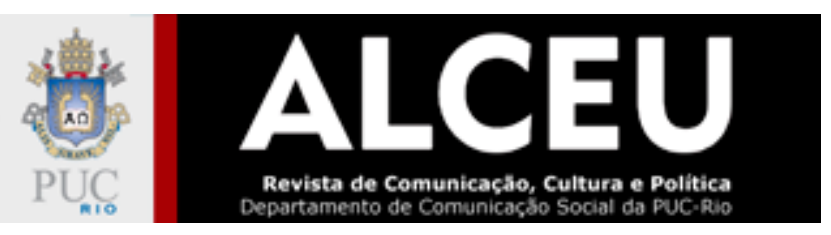

Ceiça Ferreira: Nos últimos anos, várias pesquisas acadêmicas têm apontado as desigualdades de gênero na produção cinematográfica e destacado a produção de diretoras como você, Ana Carolina, Vera de Figueiredo, Adélia Sampaio, entre outras. Mas ainda predomina uma perspectiva masculina no cinema brasileiro. Como você vê isso?

Helena Solberg: Eu acho que essa é a história do mundo! Isso não acontece só no Brasil! A gente ainda vive numa sociedade em que estamos começando a contestar uma série de coisas, aliás, começando não, porque fizeram antes de nós também. Mas é uma longa luta, porque a sociedade é machista em geral e continua sendo, quer dizer, eu acho que está acontecendo uma coisa muito interessante e muito forte e que não vai recuar. Nos anos 60 se andou para trás, houve uma reação que sempre acontece quando você força essas conquistas, você tem resultados de ataques ou reações. Agora está bastante interessante, eu acho que dessa vez a gente vai dar um passo para a frente. Às vezes acontece de você dar um para a frente e dois para trás, mas eu acho que você tem que forçar a barra.

CF: Essas questões vêm sendo discutidas cada vez mais na pesquisa em cinema, mas ainda é difícil encontrar referências sobre a produção de mulheres cineastas.

HS: É muito difícil! É também pela questão da memória. Eu acho que a gente tem que contar, a mulher tem que contar suas histórias para passar para as outras, para você ver o que há em comum.

CF: Pensando ainda essa questão da memória no cinema, no seu primeiro curta, $A$ entrevista, de 1966, você aborda a realidade da mulher carioca de classe média e assim vai na contramão da ótica cinemanovista, que priorizava a representação da alteridade social, das classes populares. De que forma você enxerga essa escolha?

HS: Na época eu não achei que eu estava fazendo uma grande escolha, ou eu não pensei nisso nesses termos, pensei que eu queria entender quem eu era, o que pra mim era essencial. Quer dizer, o outro, com o qual você tem que se confrontar, ele também é um elemento que vai te transformar se você chegar à realidade dele, mas naquele momento eu queria me entender. Venho de uma família em que eu tinha três irmãos, e eu, a única mulher. Eu não gostava da diferença da nossa educação, o que se esperava deles e o que se esperava de mim. Esperava-se que eles fossem médicos, advogados, engenheiros, e, de mim, esperava-se que eu ia casar um dia. Essa 


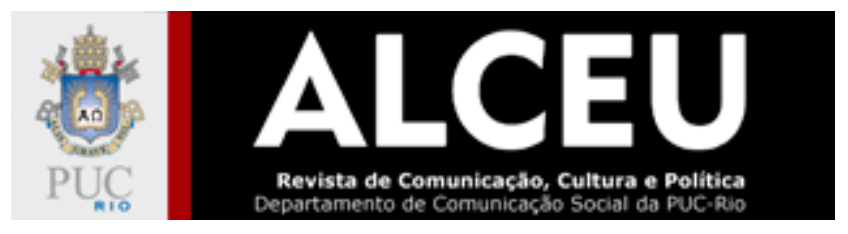

realidade me incomodava muito, e eu queria ouvir de outras mulheres, amigas, conhecidas se isso era também uma preocupação delas, ou se eu estava sozinha, se eu era maluca. Então foi uma curiosidade, uma vontade de descoberta mesmo, de querer descobrir quem eu era.

\section{CF: Como você articula no filme essas falas das mulheres com a encenação da preparação de uma noiva?}

HS: Eu usei essa imagem romantizada, essa imagem da noiva sendo preparada como para um grande sacrifício, que a sociedade esperava dela. Eu acho curioso até hoje que, se as mulheres, as moças tivessem aceitado que eu as filmasse, eu teria feito um filme de entrevistas. Mas foi exatamente a dificuldade (algo que acontece muito no documentário, e é maravilhoso) que fez o filme diferente, me obrigou a pensar numa forma de representar aquilo, e eu acho que enriqueceu muito, acho que foi o caminho certo. Porque, quando eu fui rever as entrevistas transcritas, era tão incrivel a incoerência, a loucura, a confusão dessas pessoas que eu achei que isso podia ajudar, que isso ia desconstruir essa imagem romântica e mostrar outra realidade. Acho que eu consegui e pelo menos hoje esse filme está sendo visto.

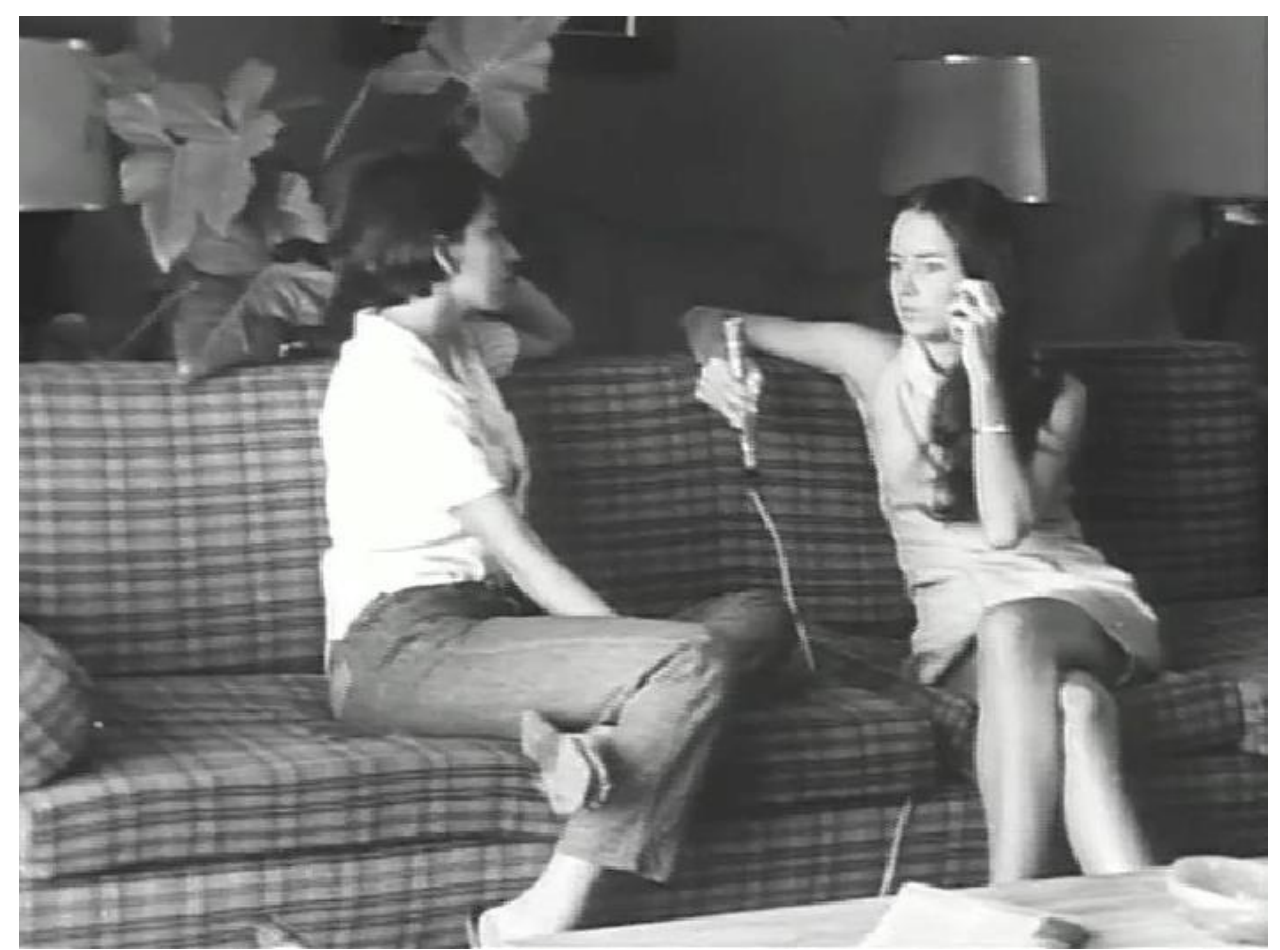

Figura 2: Helena Solberg em cena do seu primeiro filme, "A entrevista”, lançado em 1966. Fonte: A entrevista/Youtube/Reprodução 


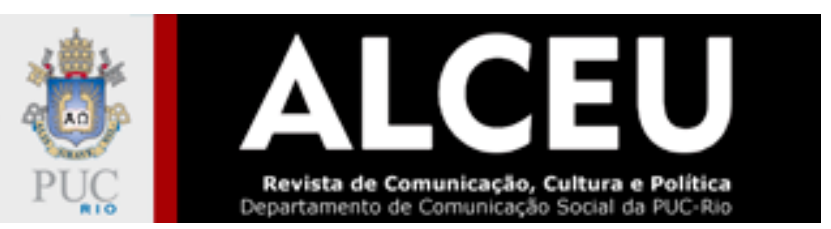

CF: Qual a influência do Cinema Novo e da convivência com cineastas vinculados a esse movimento na sua formação?

HS: Nós estávamos imbuídos disso, nós estávamos vivendo não só esses filmes [do cinema nacional], mas também os filmes do Neorrealismo Italiano, da Nouvelle Vague, que foram uma escola. Era de uma riqueza, e é evidente que isso fica dentro de você como um arquivo de imagens, de colocação de câmera, de enquadramento. Eu acho que certamente em tudo aquilo que a gente faz existe por trás os que fizeram antes, e acaba tudo sendo o mesmo caldeirão de onde vêm novas coisas.

CF: Também sobre esse contexto, gostaria que você comentasse os diálogos entre o seu segundo filme e primeira ficção, o curta Meio-dia, com esse momento de renovação no cinema, com a Nouvelle Vague e com outros filmes brasileiros que discutiram a opressão do regime militar.

HS: Eu acho que foi $67 / 68$, quando a coisa estava muito feia, bastante ameaçadora, e havia também a censura, então o filme na verdade é uma alegoria. Quando saiu a música "É proibido proibir", de Caetano - que foi proibida -, eu vi essa história, essa possibilidade. Eu gostava muito dos filmes de Jean Vigo, o Zéro de conduite (Zero de Conduta, 1933), e de Les quatre cents coups (Os incompreendidos, 1959), de François Truffaut, e eu pensei nessa ideia desse menino que está absolutamente desesperado. O filme já começa com ele colocando um plástico no rosto, uma alusão a um tipo de tortura que se usava naquela época; e ele joga os livros no rio questionando para que serve tudo aquilo, para que serve a cultura se você está sendo censurado. Depois ele tem um delírio, e aí o filme passa pra dentro de uma sala de aula, onde ele acaba com tudo aquilo, mata um professor, mas ele volta da escola correndo e vê que ela ainda está lá. Eu digo que é o meu filme anarquista, meu filme-poema!

CF: No filme The Emerging Woman (A nova mulher), que você fez nos Estados Unidos, e também nas produções seguintes, como A Dupla Jornada e Simplesmente Jenny, realizadas na América Latina, além de priorizar o ponto de vista das mulheres, observa-se a dimensão coletiva de se fazer cinema, evidenciada na atuação da equipe, composta somente por mulheres. Como hoje você avalia essa experiência na militância feminista? 


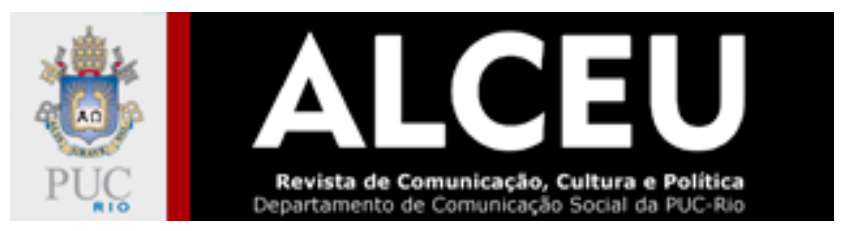

HS: Eu tinha chegado nos Estados Unidos e eu não conhecia ninguém. Estava no auge do movimento feminista americano, e eu queria entender aquilo, porque já era um feminismo organizado, havia núcleos, debates, estudos das mulheres nas universidades. E foi nesses departamentos que eu procurei quem quisesse trabalhar comigo em um projeto de um filme que contasse a história desse feminismo. O que eu queria era entender como era essa história, e aproveitava e fazia um filme. Era isso! Era muito simples! E era também o fim dos anos 60 e os anos 70 , quando havia essa ideia de repartir tudo, essa ideia de coletivos, a gente ia discutir em grupo as coisas, inclusive a autoria, havia muito isso. Eu acho que foi muito rica essa experiência, porque $A$ entrevista e Meio-dia eu fiz só, não tive esse convívio com esses grupos de debate. E, além de ter sido muito bom para a minha formação, o The Emerging Woman acabou dando muito certo porque é um filme relativamente simples, é feito com stills, com fotografias; você tem pouca imagem em movimento, mas, como é muito didático, as escolas, as universidades queriam esse filme para os estudos de mulheres. Então, para mim, foi maravilhoso! Foi uma contribuição inesperada num país estrangeiro, onde eu fui me meter a contar história.

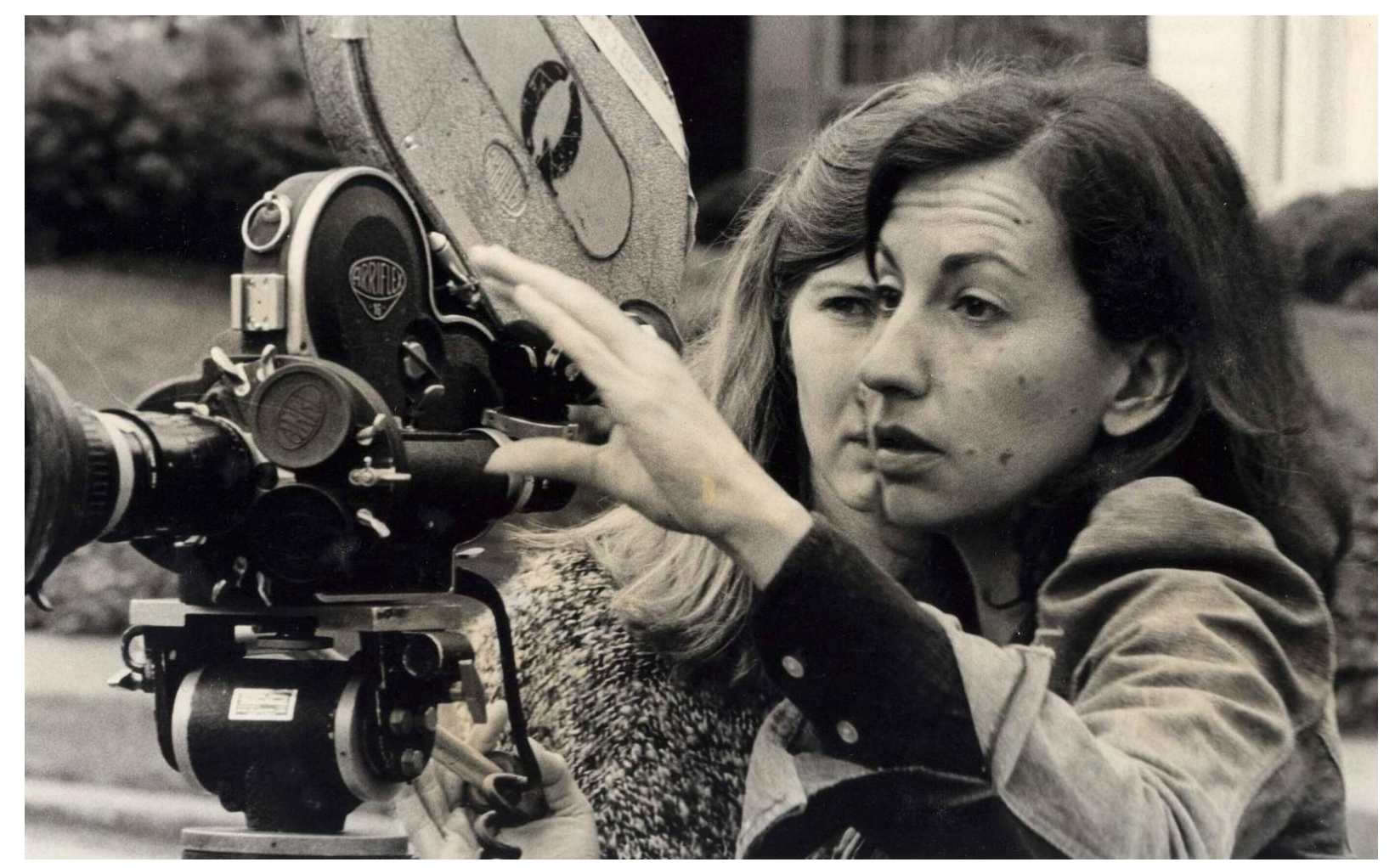

Foto 3: Helena Solberg e Christine Burrill nas filmagens de A dupla Jornada. Bolívia, 1975. Fonte: Arquivo Radiante Filmes. 
CF: É possível perceber nesse filme questões que ainda continuam em debate, como a diferença entre as mulheres, pontuando a experiência de mulheres negras e indígenas.

HS: A questão racial da mulher é muito importante no The Emerging Woman. Foi uma coisa que nós debatemos muito e achamos que era essencial não deixar de lado.

CF: Além da referência ao discurso da abolicionista afro-americana Sojourner Truth ${ }^{1}$, há também música I Wish I Knew How It Would Feel To Be Free, de Nina Simone na trilha sonora do filme.

HS: É maravilhoso esse discurso! E a música, a Nina Simone nos cedeu, porque a gente não tinha dinheiro para pagar pelos direitos, aí ela assistiu ao filme e disse: é de vocês! Foi maravilhoso! Uma outra pessoa que entrou em contato conosco naquela época foi a Yoko Ono, que ia fazer uma trilha sonora. Eu a levei para o estúdio, e ela começou a dar urros, gritava, era uma trilha sonora completamente doida, e não tinha a ver com o filme. Eu disse "não, muito obrigado!". Depois eu fiquei pensando, "puxa, se pusesse ela no filme, mesmo gritando, o filme ia ter mais distribuição". Mas não, não tinha nada a ver (risos).

CF: O seu filme Brazil in Living Colours (Brasil em Cores Vivas), que aborda o surgimento da revista Raça em 1996, tem a participação de integrantes do movimento negro nessa discussão sobre visibilidade, que hoje está ainda mais intensa.

HS: Esse filme foi encomendado pela BBC. Os ingleses viram uma notícia no jornal sobre o sucesso inesperado dessa revista, apesar de terem dito que ela não teria chance nenhuma de acontecer. Isso mostrava que havia leitores e um evidente público para esse assunto. Aí eu fui procurar o Aroldo Macedo [o criador da revista] e foi ótimo, foi interessante esse filme! Acho que agora ele teria uma audiência! Pensando nisso, acredito que foi genial a Filmes de Quintal ${ }^{2}$ ter legendado os

\footnotetext{
${ }^{1}$ Ex-escravizada, a afro-americana Sojourner Truth (1797-1883) se tornou abolicionista e ativista dos direitos da mulher negra. Na Convenção dos Direitos da Mulher (realizada em 1851, na cidade de Akron, em Ohio), ela pronunciou o discurso Não sou uma mulher? (Ain't l a woman?), no qual questiona a categoria "mulheres" e expõe a invisibilidade das mulheres negras.

${ }^{2}$ Associação cultural que organizou a mostra Retrospectiva Helena Solberg, realizada em março de 2018, no Centro Cultural Banco do Brasil (Distrito Federal, Rio de Janeiro e São Paulo) e na qual foi exibida a obra completa da cineasta.
} 


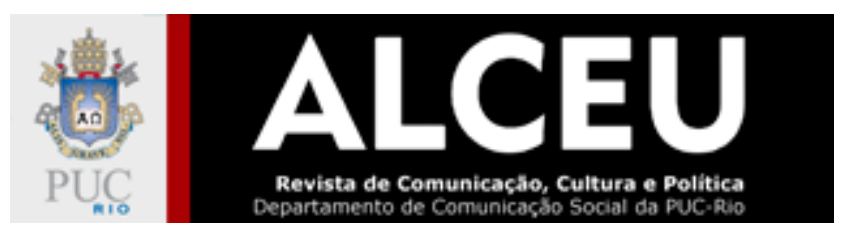

filmes, porque esses filmes nunca tinham sido vistos no Brasil. Então agora têm uma chance! Tem uma produtora que quer distribuir todos os filmes, e eu estou vendo se é possível. Já se passaram vinte, trinta anos, e alguns deles continuam atuais. Que bom que os filmes não vão ficar na prateleira! São interessantes de se ver agora por essa questão da memória, você lembrar o caminho percorrido e quem eram determinadas pessoas naquela época.

CF: Você teve mais possibilidades de fazer filmes por estar nos Estados Unidos nesse período da ditadura militar no Brasil. De que forma isso contribuiu para construção desse "olhar de fora"?

HS: Eu aprendi muito! Por exemplo, essa noção do continente da América do Sul, que quando se vive num país enorme como o Brasil (isso também acontece com os americanos), você está virado para dentro de si mesmo, você não se reconhece nos bolivianos, nos argentinos, nos chilenos. A gente não se considera parte disso! Agora que está se começando a ver essa necessidade de uma dimensão continental. Eu acho que foi uma experiência incrível filmar nesses países. Eu amo a Bolívia! A Bolívia é um dos mais interessantes da América do Sul; México, Venezuela, eu filmei em todos esses países, então foi uma descoberta pra mim, foi uma descoberta muito importante.

CF: A desconstrução das imagens femininas, em especial na propaganda, é uma questão que você aborda no filme Simplesmente Jenny e também em outros filmes. Isso nos possibilita pensar esse imaginário sobre o que é ser mulher, o que é considerado feminino. HS: Agora tem muita gente trabalhando essa questão! Isso é muito bom e vai ficar como possibilidade para outras mulheres estudarem e terem isso em arquivos. Eu acho isso sensacional!

CF: A partir da história da Jandyra dos Santos, o filme Meu corpo, minha vida destaca as histórias de várias outras mulheres que morreram e morrem em decorrência de abortos feitos em clínicas clandestinas. Você acha que essa articulação entre as dimensões do individual e do coletivo confirmam o quanto pensar gênero é político?

HS: É sempre interessante você usar o pessoal, fazer quem está assistindo se aproximar de alguém e conhecê-la bem para entender o seu drama, quais foram as opções que ela tinha. Ela tentou tudo! Não foi a família, não foi a Igreja, não foi o Estado... ninguém para socorrê-la. É uma situação 


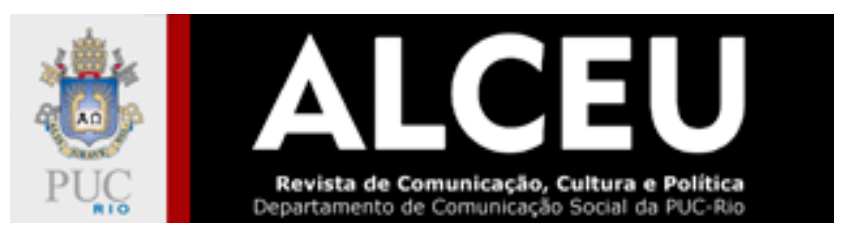

desesperadora! E o perfil dessa mulher... as Nações Unidas e a pesquisa da Débora Diniz ${ }^{3}$ dizem que essa mulher que busca interromper a gravidez e acaba buscando clínicas clandestinas é uma mulher casada, já com filhos e religiosa. Olha só a ironia! Então a ideia popular que se divulga de que essa mulher é promíscua e que por isso merecia é totalmente falsa. A gente tem que destruir esses mitos!

CF: Fica evidente nas falas de alguns entrevistados, principalmente políticos da bancada evangélica, o quanto incomoda discutir direitos reprodutivos no Brasil.

HS: Eu acho que Double Day [A Dupla Jornada] fala um pouco disso também. A ideia de que a mulher reproduz com o corpo dela a força de trabalho, é ela que gera a humanidade; e como é que isso se torna propriedade do homem ou do Estado. Enfim, tem muito o que se contar ainda.

CF: Acerca dessa naturalização das desigualdades, eu me lembro de uma sequência de $\boldsymbol{A}$ dupla jornada gravada numa escola, onde meninas e meninos estão em filas separadas para entrar no refeitório; e, ao você questionar isso ao professor, ele argumenta que é por causa do tamanho das mesas e das crianças, mas depois acaba admitindo que a divisão é por sexo. Ao ser novamente interpelado, o professor afirma que não consegue entender.

HS: Eu também adoro aquele outro entrevistado que diz que as mulheres têm as mãozinhas muito delicadas, que é para o trabalho mais tedioso e mais difícil; porque os homens são muito distraídos, não conseguem fazer esse trabalho, eles gostam é de jogar bola. Eu quase dei um beijo nele e disse obrigada pela entrevista, porque eu não acreditei que ele estava dizendo aquilo. Ele estava falando sério!

CF: Sobre o filme Carmem Miranda: Bananas is my business, em algumas entrevistas você afirma que fez uma biografia afetiva da cantora, e isso é perceptível na forma como você se propõe a conhecer a história dessa mulher, que se tornou a representação do Brasil e da América Latina durante a Política de Boa Vizinhança, e assim novamente problematiza gênero e raça.

\footnotetext{
${ }^{3}$ Antropóloga e professora da UnB, Debora Diniz é reconhecida mundialmente pela atuação no debate sobre os direitos reprodutivos das mulheres, em especial na defesa pela descriminalização do aborto no Brasil, por isso vem sendo perseguida. Em julho de 2018 , após sofrer ameaças de morte e agressão por parte de um grupo contra os direitos das mulheres ligado à extrema-direita, a pesquisadora deixou o Distrito Federal e foi incluída no programa de proteção do Governo Federal.
} 


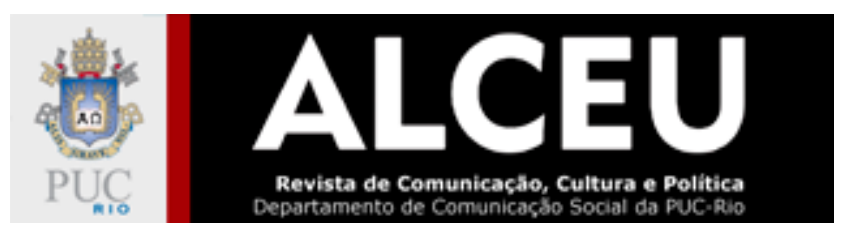

HS: Eu acho muito interessante pensar essa coisa de se traduzir para o estrangeiro e também o que se perde nessa tradução, nesse esforço de se explicar para o outro. Foi um filme difícil, eu não tinha muita ideia formada sobre aquela personagem doida com aquelas bananas na cabeça, sobre aquela mulher, mas, à medida que eu fui mergulhando na pesquisa sobre ela, eu fui vendo uma tragédia, um drama pessoal ali. Eu achei que era mesmo a história de um ícone, que tinha tantas vertentes que me interessavam, que me levavam para história dela; tinha toda essa relação BrasilEstados Unidos, a questão da mulher, do racismo, da língua, era um assunto muito rico; também foi difícil essa ideia de narrar o filme. Eu quase desisti, porque é horrível você ouvir sua própria voz. É insuportável! Eu dizia: eu não posso, eu não vou fazer isso, é ridículo! E eu fiquei trabalhando naquilo até encontrar um tom que eu me sentia confortável e que eu acho que era sincero, transmitia o que eu queria, mas foi difícil. Foi um filme difícil!

\section{CF: Esse longa possibilita, a partir das personagens que Carmem Miranda interpretava, discutir também esse imaginário sobre a mulher latina.}

HS: Sim! Tem uma entrevista com a [atriz porto-riquenha] Rita Moreno, na qual ela diz que depois de ganhar o Oscar no filme West Side Story [Amor, Sublime Amor, 1961], só era chamada para fazer papel de chiquita $^{4}$, e ela teve que recusar senão ficaria rotulada com aquilo pra sempre. É difícil, viu? É difícil ser mulher, é difícil ser latina!

Ceiça Ferreira

Professora efetiva no curso de Cinema e Audiovisual da Universidade Estadual de Goiás Doutora em Comunicação pela Universidade de Brasília ORCID: https://orcid.org/0000-0003-0625-6923 E-mail: ceicaferreira.ueg@gmail.com

Recebido em: 4 de abril de 2019 .

Aprovado em: 27 de maio de 2019.

\footnotetext{
${ }^{4}$ Chiquitas e Rositas eram personagens femininas de origem latino-americana, comumente caracterizadas de forma extravagante e estereotipada em comédias musicais.
} 


\section{Referências}

AMARAL, Leonardo; ITALIANO, Carla (Orgs.). Catálogo Retrospectiva Helena Solberg. Belo Horizonte: Filmes de Quintal, 2018.

ARAÚJO, Mateus; SOUTO, Mariana. Um 1968 mirim? Notas sobre Meio-dia, de Helena Solberg. Revista ECO-Pós, v. 21, n. 1, p. 263-276, 2018. Disponível em: < https://revistas.ufrj.br/index.php/eco_pos/article/view/18505/11062>. Acesso em: 11 fev.2019.

TAVARES, Mariana Ribeiro. Helena Solberg: do cinema novo ao documentário contemporâneo. São Paulo: Imprensa Oficial, 2014.

Da militância feminista ao documentário contemporâneo: a trajetória incomum de Helena Solberg. In: SEMINÁRIO INTERNACIONAL FAZENDO GÊNERO 11 \& 13th WOMEN'S WORLDS CONGRESS, 2017a, Florianópolis. Anais Eletrônicos...2017a, p.1-12. Disponível em: <http://www.wwc2017.eventos.dype.com.br/site/anaiscomplementares\#D>. Acesso em 11 fev. 2019.

Helena Solberg: militância feminista e política nas Américas. In: HOLANDA, Karla; TEDESCO, Marina Cavalcanti. (orgs.). Feminino e plural: Mulheres no cinema brasileiro. Campinas, SP: Papirus, 2017b, p. 89-100.

\section{Resumo}

A cineasta Helena Solberg tem um papel fundamental na história do cinema brasileiro, pelo pioneirismo e pelo legado crítico de sua filmografia realizada nas últimas cinco décadas, que abrange o Cinema Novo, a militância feminista nos Estados Unidos e na América Latina, a ficção e o documentário contemporâneo. Apesar dessa trajetória singular, é somente em 2014 que essa cineasta começa a ser reconhecida no Brasil. Ao longo da entrevista que se segue, Helena Solberg aponta as inquietações que a levaram a fazer cinema nos anos de 1960, suas referências estéticas, experiências e trabalhos mais recentes, nos quais reitera seu engajamento político.

Palavras-chave: cinema brasileiro; Helena Solberg; documentário contemporâneo; militância feminista.

\section{Abstract}

The filmmaker Helena Solberg has a fundamental role in the history of Brazilian cinema, for the pioneering and critical legacy of her filmography in the last five decades, which includes Cinema Novo, feminist militancy in the United States and Latin America, fiction and contemporary documentary. Despite this unique trajectory, it is only in 2014 that this filmmaker begins to be recognized in Brazil. Throughout the following interview, Helena Solberg points out the concerns that led her to make movies in the 1960s, her aesthetic references, experiences and more recent works, in which she reiterates their political engagement.

Keywords: Brazilian cinema; Helena Solberg; contemporary documentary; feminist militancy. 


\section{Resúmen}

La cineasta Helena Solberg desempeña un papel clave en la historia del cine brasileño, por el legado pionero y crítico de su filmografía en las últimas cinco décadas, que abarca el Cinema Novo, el activismo feminista en los Estados Unidos y América Latina, la ficción y el le Documental contemporáneo. A pesar de esta trayectoria única, es solo en 2014 que esta cineasta comienza a ser reconocida en Brasil. A lo largo de la siguiente entrevista, Helena Solberg señala las preocupaciones que la llevaron al cine en la década de 1960, sus referencias estéticas, experiencias recientes y trabajos en los que reitera su compromiso político.

Palavras clabe: Cine brasileño; Helena Solberg; Documental contemporáneo; militancia feminista. 